\title{
Fixed Exchange Rate or Flexible Exchange Rate for Saudi Arabia: optimal solution of CGE model
}

\author{
Imtithal A. AL-Thumairi \\ University of King Saud \\ Department of Economics, Telephone (+966) (0) 14674150, Facsimile (+966) (0) \\ 14674147 , \\ e-mail: thumairi@ksu.edu.sa, thumairi@gmail.com
}

\begin{abstract}
When analyzing the impact of changes in oil and petroleum prices on Saudi Arabia's economy the results indicate that adjustments in foreign savings, supporting an unchanged real exchange rate in the context of changes in oil world prices, quite effectively can insulate the domestic economy from international price fluctuations. If the economy is forced to adjust to the fall in world prices without offsetting changes in foreign savings, the resulting loss of export earnings and associated depreciation have major impacts on aggregate absorption, and the structure of production.
\end{abstract}

Keywords: Computable general equilibrium model, Social Accounting Matrix, exchange rate, Saudi Arabian economy..

\section{Introduction}

Inflation in Saudi Arabia has been accelerating over the past three years. One possible explanation for accelerating inflation has been the riyals' dollar peg, given that USD since January 2006 has weakened 19.5\% against the euro and 7\% against the yen. This effective weakening of the Saudi exchange rate could drive up inflation through imported inflation, aggregate demand, and wages. 
One policy frequently debated is a revaluation of the riyal against the dollar or a switch to a basket of currencies. The reasoning is that this would help contain inflationary pressures, some of which trace to higher import prices resulting from the weaker dollar. However, it is appeared that the SAR will remain pegged to the USD through the end of 2010. Given Saudi Arabia's economic structure, the dollar peg makes sense as oil (a USD-denominated commodity) represents $47 \%$ of GDP, $90 \%$ of exports and around $80 \%$ of all fiscal revenues. The authorities are trying to build up the non-hydrocarbon sector to reduce reliance on oil revenues in the future, and a revaluation would make this sector less competitive.

Using a Computable General Equilibrium (CGE) model of Saudi Arabia (SAUMOD) I will attempt to evaluate the impact of important policies related to Saudi Arabia's Exchange Rates options. These policies are divided into two categories of policy simulations. The scenarios aimed at finding out the impact of increases and decreases in the world oil and refined petroleum products of 25 percent with different closure rules across the simulations. The first Closure rule is to have this increase in oil price with Fixed Exchange Rate (the riyals' dollar peg). The second Closure is to have this increase in oil price with Flexible Exchange Rate.

The CGE model provides a laboratory for doing controlled experiments, changing parameters and exogenous variables and computing the impact of those changes on the economy. The results of these experiments provide information about the empirical magnitudes of such impacts, linking them to changes in the economic environment (e.g., world prices) and/or particular policy instruments. The use of simulation models to do "counterfactual experiments" is useful for policy analysis, allowing the analyst to isolate the impact of particular policy changes or exogenous shocks. Such experiments, however, do not provide forecasts of how an economy will change over time. Forecasting requires projections of changes in all exogenous variables and parameters, while counterfactual simulations involve changing only a few, selected, exogenous variables and parameters.

The model adopted by this study is a neoclassical CGE model which will lead to numerous microeconomic and macroeconomic results for each policy simulation. This paper, however, will provide a systematic comparison between the counterfactual equilibrium and the benchmark equilibrium of the same year in order to analyze the effects of the option experiments on macroeconomics variables.

\section{Literature Review}

Since Johansen's (1960) model of Norway, applied or computable general equilibrium models have grown in importance, as a tool of both research and 
policy analysis. Initially confined to universities and research institutions, CGE models today are routinely used by governments in policy formulation and debate (Robinson and Devarajan, 2002). The range of issues on which CGE models have had an influence is quite wide, and includes international trade, public finance and taxation policy, agriculture, structural adjustment policies, labour market, income distribution, natural resources management, and pollution abatement. Specifically, these models can ascertain the potential winners and losers from changes in policies and the external environment, and indicate, what, if any, policies could be implemented to ease the transition from one equilibrium to another (ven der Mensbrugghe, 1998). The main advantage of CGE models - over other types of economy wide models - is their consistency with micro-economic theory and their high degree of structural detail.

The key edge of CGE models over so-called partial equilibrium models is the endogeneity of both product and factor markets, and the feedback effects between changes in income and product demand. Further, it can provide a more complete evaluation of welfare impacts, including distribution effects in models which incorporate multiple households. In this context, there is a well established and fast growing body of literature that focuses on economic policy evaluation using disaggregated CGE models. This is because: (i) the CGE methodology allows the study of differential impacts across sectors of production and across consumer groups; (ii) it allows interactions among different sectors and agents of the economy, so the policy evaluation is not biased by ceteris paribus assumptions; (iii) the CGE methodology, in a more technical vein, uses flexible computational numerical techniques, analytical tools often become intractable for disaggregated models.

CGE models have their antecedents dating back to Leon Walras in the late nineteenth century. Walras, in his mathematical model, summarized the economic system in a set of excess demand equations in as many unknown prices. However, Walras was unsuccessful in his attempt to prove the existence of a unique equilibrium price vector that would solve his general equilibrium model simultaneously. He justified the existence of the solution by referring to the equality between the number of endogenous variables (prices) and the number of equations in his model. Walras also argued theoretically that a tatonnement process would guarantee the existence of the solution through successive price revisions that occur as a result of the discrepancy between quantities demanded and quantities supplied.

The conditions for the existence and uniqueness of the general equilibrium solution were not proved rigorously until 1951. Arrow (1951), Arrow and Debreu (1954), Gale (1955), and others who used the Brouwer's theorem to establish the consistency of the Walrasian model demonstrated this proof (Scarf and Hansen, 1973).

The application of general equilibrium models had to wait until computational techniques such as fixed point or numerical analysis approaches became available. 
Lief Johansen's (1960) earlier work was the first empirical CGE model that was developed and tested using real data. He used his model to analyze policies related to resource allocation issues in Norway. His model assumed that factors of production (capital and labour) are fully employed and also perfectly mobile between sectors. Johnsen first linearized and then solved his model's equations by simple matrix inversion.

Another earlier work on the CGE model was that of Arnold Harberger (1962), who was the first to numerically analyze income tax policy applied to the United States' economy. He developed a two-sector, corporate and no corporate, general equilibrium framework to find equilibrium tax schedules for each sector.

The work of Scarf (1967) which develops a reliable algorithm to compute equilibrium prices for an Arrow-Debreu economy give rise to the emergence of 'computable general equilibrium, CGE, models'. These three contributions of Johnsen, Harberger, and Scarf (as Shoven and Whalley described them) provide background and stimulus for most of the general equilibrium models applying contemporary numerical methods (Shoven and Whalley, 1973).

The high cost of implementing numerical solutions has kept general equilibrium models from becoming popular. It was until the early 1970's, when the numerical solutions became cheaper and more common to solve, that CGE models gained popularity in economic modelling (Tawi, 1989).

In the early 1970's, the problem of income distribution was a prime concern for policy makers in developing countries. The Johansen's model (1960) and other CGE models present at that time did not address income distribution explicitly. The first model along this line was the Adelman-Robinson (1978) model of South Korea which was developed to explore the feasibility of using various policy instruments to change the distribution of income. A later model was constructed for Brazil which also focused on income distribution. These two models introduced a number of structural changes and incorporated basic structural variables in order to capture the stylized facts that characterize developing countries and are important to capture significant forces that effect income distribution. Later on, these two models were extended to allow for substitutability between local and imported goods- an assumption which was not used in either the original Korea or Brazil models (Adelman and Robinson, 1987). Since then, a steady stream of CGE models has flourished with applications for more that 30 developing countries exploring a variety of economic issues.

Computable General Equilibrium (CGE) models can be classified by feature of policies or issues they handle. Economists have used CGE models to study income distribution effects as well as for simulating international trade policies. They have used some applications to evaluate tax policies and also evaluate oil price effects.

CGE models have the feature of capturing most of the interactions of the different actors in the economy and hence, they are useful to analyze a wider range of policies efficiently. The following is a sample of historical studies grouped according to the major policy that is central to them: 
1. Tax models: all general equilibrium tax models are built, in one way or another, on the work of Harburger (1962) using United States data. These models help economists mainly to evaluate tax policies in developed countries. In particular, they are used to compare the two equilibrium solution values before and after introducing changes in the tax system. Whalley (1977) also used this tax policy model to analyze the impact of 1973 tax changes in the United Kingdom. Several more tax policy models of this type were constructed by Greg et al (1979) on Canada, Keller's (1980) on Holland, Riggot (1980) on Australia, and Jiam Serra-Puche (1984) on Mexico.

2. Trade Policy models: after the first oil crisis in 1973 and the second crisis in 1975, both developing country policy makers and international lending agents focused their attention on questions of structural adjustment in production and trade in order to adapt increased scarcity of foreign exchange. General equilibrium models have also focused on the issue of tariff abolition and some other correction policies for trade distortion. These studies include the ones by Boadway, et al (1978) for Canada, Evans (1972) for Austoralia, de Melo and Dervis (1977) for Turkey, Michel and Noel (1984) for Ivory Coast.

3. Income distribution policy models: in the early 1970's, policy interests shifted to a concern about changing the distribution of income. Specifically, the concern shifted to the implication of a certain policy or development strategy on the distribution of income. What would be the best policy package that would reduce the worsening of income distribution arising from rapid growth and structural changes. There was a growing concern that large groups of poor people were not deriving any benefit from growth. The CGE model handles such issues very efficiently since prices and income of different socioeconomic groups can be incorporated directly in the model. The first CGE model developed to explore questions of income distribution was the Adelman and Robinson (1978) model of South Korea and later, the Lysy and Taylor (1980) model of Brazil. The Adelman and Robinson model incorporates up to 15 households groups, adjusting capital stocks and labour supplies by skill type yearly in this model. Other models of this category have been constructed and applied to several other countries of interest. Examples of these models are de Melo and Robinson (1980) for Colombia, Bourguignon, et al (1983) for Venezuela, and Eckaus, Mohie-Eldin (1984) for Egypt, and Norton et al (1986) for Portugal.

4. Food Policy Models: although most CGE models incorporate some agriculture policies, some of the models contain detailed specifications of the agriculture sector and food issues. In these models, the agriculture sector is disaggregated into several food processing and agricultural producing sectors in order to gain better insight about the impact of some policies on the agriculture sector. Some of them focus on the impact of food and fertilizer subsidies on some household classes and some agricultural products. Examples of these models are Duloy and Norton (1973) for Mexico and Norton (1985) for Bangladesh.

5. Energy Policy Models: the main policy focus of this group is on substitution possibilities for oil especially after the oil crisis of 1973 . Hudson and 
Jorgenon (1974) conducted the first work in this area for the United States. Other models such as Berndt and Field (1981) and Borger and Goulder (1984) followed them.

\section{Research Methodology}

To capture these effects dynamic multi-sectors computable general equilibrium model (SAUMOD) will be used for the case of Saudi Arabia in order to evaluate policy options and assess the policy changes. The Computable General Equilibrium (CGE) models have obvious advantages in the analyses of complex policy reforms. Generally, (CGE) models provide a quantitive, comprehensive view of production, consumption, and trade in an economy. They include a disaggregated treatment of producers and consumers, making it possible to consider linkages between different sectors, between production and consumption, and between macro and micro levels of economy. Over the past twenty-five years, CGE models have become a standard tool of empirical economic analysis. The payoffs from this type of analysis have increased as a result of improvements in model specification, data availability, computer technology, and the skills of policy analysts. While their starting point is the Walrasian market economy, the incorporation of a wide variety of government policies and market rigidities have permitted the new generation of this class of models to capture structural features that typical of real-world economies.

\section{Model Description}

The model is in the neoclassical-structuralist modelling tradition presented in Dervis et al. (1982). It incorporates additional features developed by Lofgren, Robinson, Thomas, and El-Said (2002). It is formulated as a simultaneous equation system, including both linear and non-linear equations. The equations capture the full circular flow of payments including production (activities producing outputs using factors and intermediate inputs), consumption (by households and the government), investment (private and public), trade, other government revenue and spending activities, as well as the market equilibrium conditions, macro-balances and dynamic updating equations under which the agents operate.

\section{Production}

Each producer (represented by an activity) is assumed to maximize prof $\neg$ its, defined as the difference between revenue earned and the cost of fac $\neg$ tors and 
intermediate inputs. Profits are maximized subject to a nested produc 7 tion function. At the first nest, the technology is specified by a constant elasticity of substitution (CES) function or, alternatively, a Leontief function of the quantities of value-added and aggregate intermediate input. The Leontief alternative is the default. The CES alternative may be preferable for particular sectors to allow for substitution possibilities in the choice of production factors. Value-added is itself a CES function of primary factors whereas the aggregate in $\neg$ termediate input is a Leontief function of disaggregated intermediate inputs. Each activity produces one or more commodities according to fixed yield coefficients. As noted, a commodity may be produced by more than one activity. The revenue of the activity is defined by the level of the activity, yields, and commodity prices at the producer level.

Unless additional factor-related constraints are imposed, the essence of the activity profit-maximizing decision involves employing a set of fac $\neg$ tors up to the point where the marginal revenue product of each factor is equal to its factor price. Factor wages may differ across activities, not only when the market is segmented but also for mo $\neg$ bile factors. In the latter case, the model incorporates discrepancies that stem from exogenous causes (for example, wage differences across activiᄀties resulting from considerations such as status, comfort, or health risks). Factor incomes are distributed to domestic and foreign institutions in fixed shares that are defined by factor and activity. The fact that they are disaggregated by activity is a Saudi-Specific extension.

\section{Institutions}

In the CGE model, institutions are represented by households, enter-prises, the government, and the rest of the world.

The households (disaggregated as in the SAM for Saudi and non-Saudi households) receive income from the factors of production and transfers from other institutions. The households use their income to pay direct taxes, save, con $\neg$ sume, and make transfers to other institutions. Direct taxes and transfers to other domestic institutions are defined as fixed shares of household income whereas the savings share is flexible for selected households. The income that remains after taxes, savings, and transfers to other institutions is spent on consumption. 
Household consumptions purchased at market prices (incorporating or adjusted for taxes). In many CGE models household expenditure behaviour functions are derived from the maximization of Cobb-Douglas or Constant Elasticity of Substitution (CES) utility. The limitation of using these functional forms for consumption is that they imply a unitary income elasticity of demand. This fails to account for the way changes in income affect the structural adjustment of the economy to exogenous shocks. In order to avoid such drawbacks, household consumption in the current model is allocated according to linear expenditure system (LES) demand functions, derived from maximization of a Stone-Geary utility function.

Instead of being paid directly to the households, factor incomes may be paid to one or more enterprises. Enterprises may also receive transfers from other institutions. Enterprise incomes are allocated to direct taxes, savings, and transfers to other institutions. Enterprises do not consume. Apart from this, the payments to and from enterprises are modelled in the same way as the payments to and from households.

The government collects taxes and receives transfers from other instiᄀtutions. All taxes are at fixed ad valorem rates. Transfers from the rest of the world are exogenous in foreign currency whereas transfers from domestic institutions are fixed shares of the net (post-tax and post-savings) incomes of these institutions. The government uses this income to finance its own consumption, commodity subsidies, and for transfers to other institutions. Government consump 7 tion is fixed in real (quantity) terms whereas government transfers to do $\neg$ mestic institutions (households and enterprises) are CPI-indexed. Gov $\neg$ ernment savings (the difference between government income and spend $\neg$ ing) is a flexible residual.

The final institution is the rest of the world. In addition to transfer payments from the rest of the world to domestic institutions and factors (which all are fixed in foreign currency), Saudi Arabia receives payments from the rest of the world for exports. Saudi Arabia spends pays transfers to the rest of the world modelled as fixed net-income shares for domestic non-government institutions but fixed in foreign currency for the government and imports. Foreign savings (or the current account deficit) is the difference between foreign currency spending and receipts. The treatment of trade with the rest of the world is explained in the discussion of commodity markets, which follows next. 


\section{Commodity Markets}

All commodities (domestic output and imports) enter markets. Domestic output may be sold in the market or consumed at home. For marketed output, the first stage in the chain consists of generating aggre-gated domestic output from the output of different activities of a given commodity. These outputs are imperfectly substitutable as a result of, for example, differences in timing, quality, and distance between the locations of activities. A CES function is used as the aggregation function. The de-mand for the output of each activity is derived from the problem of mini-mizing the cost of supplying a given quantity of aggregated output subject to this CES function. Activity-specific commodity prices serve to clear the implicit market for each disaggregated commodity. At the next stage, aggregated domestic output is allocated between ex $\neg$ ports and domestic sales on the assumption that suppliers maximize sales revenue for any given aggregate output level, subject to imperfect transformability between exports and domestic sales, expressed by a constant elasticity of transformation (CET) function. In the international markets, export demands are infinitely elastic at given world prices. The price reרceived by domestic suppliers for exports is expressed in domestic currency and adjusted for the transaction costs (to the border) and export taxes (if any). The supply price for domestic sales is equal to the price paid by do $\neg$ mestic demanders minus the transaction costs of domestic marketing (from the supplier to the demander) per unit of domestic sales. If the com $\neg$ modity is not exported, total output is passed to the domestic market. Domestic demand is made up of the sum of demands for household consumption, government consumption, investment (the determination of which is discussed below), intermediate inputs, and transactions (trade and transportation) inputs. If the supply of a commodity destined for domestic use is made up of both imports and domestic output, then all domestic market de $\neg$ mands are for a composite commodity made up of imports and domestic output, the demands for which are derived on the assumption that do $\neg$ mestic demanders minimize cost subject to imperfect substitutability. This is also captured by a CES aggregation function. Total market demand is directed to imports for commodities that lack domestic production and to domestic output for non-imported commodities. Demand prices are adjusted for commodity taxes and subsidies. The derived demands for imported commodities are met by interna $\neg$ tional supplies that are infinitely elastic at given world prices. The import prices paid by domestic demanders also include import tariffs (at fixed ad valorem rates) and the cost of a fixed quantity of transactions services per import unit, covering the cost of moving the commodity from the border to the demander. 
Similarly, the derived demand for domestic output is met by domestic suppliers. The prices paid by the demanders include the cost of transactions services (if such cost is treated explicitly in the SAM); in this case reflecting that the commodity was moved from the domestic supplier to the domestic demander. The prices received by domestic suppliers are net of these transaction costs. Flexible prices equilibrate demands and supplies of domestically marketed domestic output. Compared with the alternative assumptions of perfect substitutability and transformability, the assumptions of imperfect transformability (be $\neg$ tween exports and domestic sales of domestic output) and imperfect sub $\neg$ stitutability (between imports and domestically sold domestic output) permit the model to better reflect the empirical realities. The assumptions used give the domestic price system a degree of independence from international prices and prevent unrealistic export and import responses to economic shocks. At the disaggregated commodity level, these assumptions allow for a continuum of tradability and two-way trade, which is commonly observed even at very fine levels of desegregations.

\section{Policy scenarios}

The first category of Simulations consists of two scenarios aimed at finding out the impact of increases and decreases in the world crude oil and refined petroleum products of 25 percent with different closure rules across the simulations. In the first set of simulations, we assume that the government reacts to the oil-price shock by allowing foreign savings to adjust sufficiently to keep the exchange rate fixed. In the second set of simulations, however, the government is assumed to keep foreign savings at the base level, forcing the adjustment to the oil-price shock onto the domestic economy.

The assumptions for the oil price simulations with different Exchange Rate are described in table (1). For this set of simulations, I will analyze the impact of increases and decreases in the world prices of oil and refined petroleum products of $25 \%$. The simulations are different, not only in terms of the direction of the oil price change but also in terms of how the economy will respond at the macro level; i.e. the closure rules differ across the simulations: 
Table (1): The assumptions for the oil price simulations with different Exchange Rate

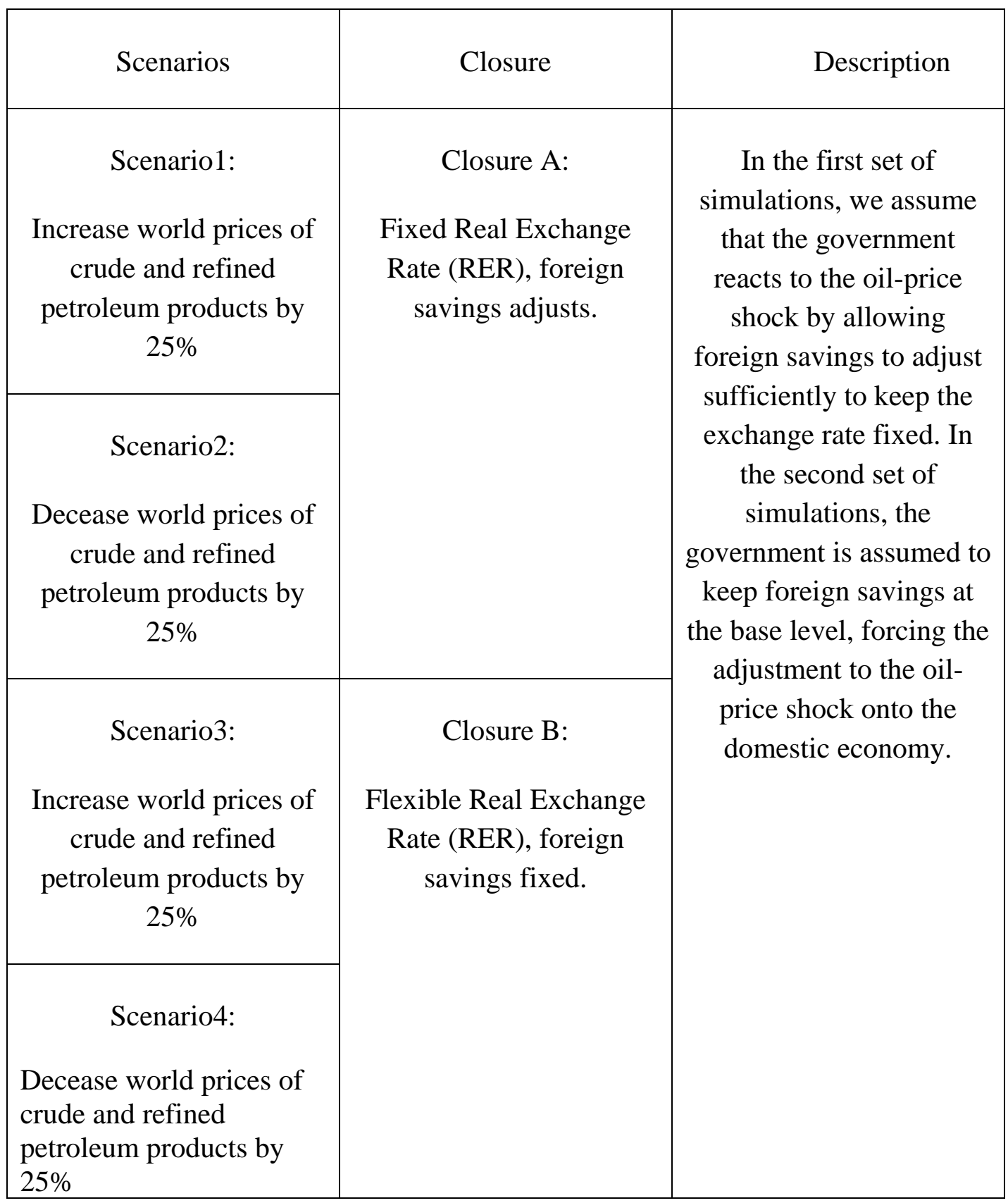


- $\quad$ Oil price changes with fixed (RER) and adjustable savings:

The government responds to the changes in world prices of oil and refined petroleum by allowing foreign savings to adjust sufficiently to keep the exchange rate fixed. The intent would be to insulate the domestic economy from the impact of the change in world prices.

\section{- Oil price changes with flexible (RER) and fixed savings:}

In the second set of experiments, the government is assumed to keep foreign savings at the base level, forcing the domestic economy to adjust to the oil-price shock. The real exchange rate will have to depreciate (appreciate) in order to adjust to the loss (increase) in export earnings from oil price changes.

The effects of negative and positive oil price changes are different with closure rule $B$ (i.e. flexible real exchange rate and foreign savings fixed).

\section{Simulations Results}

\subsection{Oil price changes with fixed (RER) and adjustable savings}

The government responds to the changes in world prices of oil and refined petroleum by allowing foreign savings to adjust sufficiently to keep the exchange rate fixed. The intent would be to insulate the domestic economy from the impact of the change in world prices. Tables (2), (3), (4) summarize the macroeconomic results of the oil price simulations. 
Table (2): Macroeconomic effects of the Oil Price Simulations baseline (mn.SR)

\begin{tabular}{|c|c|c|c|}
\hline $\begin{array}{l}\text { MACROECONOMIC } \\
\text { RESULTS } \\
\text { BASELINE }\end{array}$ & 2005 & 2010 & 2015 \\
\hline $\begin{array}{l}\text { Government } \\
\text { Consumption }\end{array}$ & 183805.00 & 183805.00 & 183805.00 \\
\hline Absorption & 754029.39 & 957998.29 & 1192438.0 \\
\hline Private Consumption & 387524.34 & 549768.17 & 743003.60 \\
\hline Total Real Exports & 344611.83 & 401101.83 & 467482.50 \\
\hline Total Real Imports & -207707.83 & -264197.83 & -330579.0 \\
\hline Foreign Savings & -48168.01 & -49900.55 & -51173.57 \\
\hline GDP at market prices & 893507.33 & 1104375.76 & 1350359.0 \\
\hline Net-indirect taxes & 29305.45 & 37363.33 & 46646.20 \\
\hline GDP at factor cost & 864201.88 & 1067012.42 & 1303712 \\
\hline
\end{tabular}

Note: Baseline: projected dynamic path without shock. Foreign savings is the current account deficit. 
Table (3): Macroeconomic effects Closure A

(\% change compared with the baseline)

\begin{tabular}{|l|l|l|l|l|l|l|}
\hline $\begin{array}{l}\text { Change Oil } \\
\text { Price with } \\
\text { Closure A }\end{array}$ & INC & DEC & INC & DEC & INC & DEC \\
\hline $\begin{array}{l}\text { Absorption } \\
\text { Private }\end{array}$ & -0.24 & 0.26 & -0.46 & 0.54 & -0.81 & 0.92 \\
\hline $\begin{array}{l}\text { Consumption } \\
\text { Total Real }\end{array}$ & -0.39 & 0.42 & -0.76 & 0.89 & -1.2 & 1.4 \\
\hline $\begin{array}{l}\text { Exports } \\
\text { Total Real } \\
\text { Imports }\end{array}$ & -0.21 & -0.48 & 0.77 & -1.05 & 1.89 & -2.14 \\
\hline $\begin{array}{l}\text { Foreign } \\
\text { Savings }(\% \\
\text { of GDP) }\end{array}$ & -3.43 & 3.74 & -6.60 & 7.84 & -13.24 & 14.25 \\
\hline $\begin{array}{l}\text { GDP ax } \\
\text { factor cost }\end{array}$ & 0.07 & -0.09 & 0.15 & -0.20 & 0.45 & -0.50 \\
\hline
\end{tabular}


Table (4): Macroeconomic effects Closure B

(\% change compared with the baseline)

\begin{tabular}{|c|c|c|c|c|c|c|}
\hline $\begin{array}{c}\text { Change Oil } \\
\text { Price with } \\
\text { Closure B }\end{array}$ & INC & DEC & INC & DEC & INC & DEC \\
\hline $\begin{array}{c}\text { Absorption } \\
\text { Private } \\
\text { Consumption }\end{array}$ & 4.52 & -4.70 & 8.96 & -9.72 & 15.21 & -16.59 \\
\hline $\begin{array}{c}\text { Total Real } \\
\text { Exports }\end{array}$ & -2.65 & 3.13 & -4.86 & 6.77 & -10.54 & 12.67 \\
\hline $\begin{array}{c}\text { Total Real } \\
\text { Imports }\end{array}$ & 9.10 & -8.48 & 18.78 & -16.32 & 20.91 & -18.58 \\
\hline $\begin{array}{c}\text { Foreign } \\
\text { cost }\end{array}$ & 3.11 & -3.86 & 5.65 & -8.70 & 14.22 & -15.76 \\
\hline $\begin{array}{c}\text { Gavings (\% of } \\
\text { GDP) }\end{array}$ & -0.55 & 0.44 & -1.15 & 0.63 & -2.13 & 0.89 \\
\hline $\begin{array}{c}\text { GDP at } \\
\text { fot-indirect }\end{array}$ & 1.06 & -2.25 & 4.24 & -6.07 & 8.97 & -12.17 \\
\hline
\end{tabular}


The effect of negative and positive oil price changes are symmetric except for the fact that the directions of changes are reversed, a positive price shock leads to roughly the same changes as a negative price shock of the same magnitude.

It is clear from the simulations results presented in table (3) that a policy of keeping the exchange rate fixed as described in the preceding paragraph does insulate the domestic economy from the price shocks. When the world price of oil and refined petroleum products decreases (increases), this policy leads to a small depreciation (appreciation) of the real exchange rate defined as the ratio of the prices of traded goods to non-traded goods. The current account deficit declines (increases) - foreign savings become less (more) negative- maintaining absorption and its components close to the base levels. It can be seen that the changes in real absorption and its components are all minor. During the current boom: a 10\% increase in world prices of crude and refined petroleum products, the total absorption and private consumption both decline for less than $-1.5 \%$. Total real imports decrease by $-0.21 \%$ in $2005,-0.41 \%$ in 2010 , and $-1.2 \%$ in 2015 . Total real exports increase by $0.41 \%$ in $2005,0.77 \%$ in 2010 , and $1.89 \%$ in 2015 . Total effect on the GDP is positive which will increase by $0.07 \%$ in $2005,0.14 \%$ in 2010, and $0.5 \%$ in 2015 .

The fixed exchange rate prevents any changes in domestic prices for traded commodities other than oil and petroleum products. The foreign savings variable shows the cost of insulating the domestic economy from the price shocks. When the world oil price increases the foreign savings as a percentage of GDP declines by $-3.43 \%$ in $2005,-6.60 \%$ in 2010 , and $-13.24 \%$ in 2015 .

On the other hand, when the world price of oil and petroleum products declines, this brings positive effect on the total absorption and its components. Total absorption increase by $0.26 \%$ in $2005,0.54 \%$ in 2010 , and $0.92 \%$ in 2015 . The private consumption increase by $0.42 \%$ in $2005,0.89 \%$ in 2010 , and $1.4 \%$ in 2015. Total real imports increase by $0.21 \%$ in $2005,0.42 \%$ in 2010 , and $1.3 \%$ in 2015. Total real exports, however, decline by $-0.48 \%$ in $2005,-1.05 \%$ in 2010 , and $-2.14 \%$ in 2015 . The total effect from this simulation on the real GDP is negative for less than $-0.5 \%$.

\subsection{Oil price changes with flexible (RER) and fixed savings:}

In the second set of experiments, the government is assumed to keep foreign savings at the base level, forcing the domestic economy to adjust to the oil-price 
shock. The real exchange rate will have to depreciate (appreciate) in order to adjust to the loss (increase) in export earnings from oil price changes.

The effects of negative and positive oil price changes are different with closure rule $B$ (i.e. flexible real exchange rate and foreign savings fixed).

In this setting- table (4)-, the increase in the world price leads to noticeable increase in real absorption and private consumption. Total absorption increase by $4.52 \%$ in $2005,8.96 \%$ in 2010 , and $15.21 \%$ in 2015 . Private consumption also increases by $7.4 \%$ in $2005,14.69 \%$ in 2010 , and $24.11 \%$ in 2015 . Total real imports increase by $9.1 \%$ in $2005,18.78 \%$ in 2010 , and $20.91 \%$ in 2015 . Total real exports, however, decline by $-2.65 \%$ in $2005,-4.86 \%$ in 2010 , and $-10.54 \%$ in 2015. The total effect from this simulation on the real GDP is negative leading to a decline by $-0.55 \%$ in $2005,-1.15 \%$ in 2010 , and $2.13 \%$ in 2015 .

When the world price of oil and petroleum products decline with this closure, the adjustments are also severe affecting all macro aggregates. Total absorption and its components show substantial decline. For example, the household consumption decrease by $-7.69 \%$ in $2005,-15.93 \%$ in 2010 , and $-25.44 \%$ in 2015 . Total real imports decline by $-8.48 \%$ in $2005,-16.32 \%$ in 2010 , and $-18.58 \%$ in 2015.

In sum, the impact of changes in the world prices of oil and petroleum products is significant for an oil-producing country such as Saudi Arabia. Given the size of foreign savings from oil revenues, the government can minimize the impact of price falls on the domestic economy by varying foreign savings to offset variations in export revenues, thereby supporting a relatively stable real exchange rate. Such policies, aiming at maintaining the exchange rate, can ameliorate the impact of changes in world prices. If the economy is forced to adjust to the fall in world prices without offsetting changes in foreign savings, the resulting loss of export earnings and associated real depreciation have major impacts on aggregate absorption and the structure of production. 


\section{Conclusion}

The outcome is that, when analyzing the impact of changes in oil and petroleum prices on Saudi Arabia's economy the results indicate that adjustments in foreign savings, supporting an unchanged real exchange rate in the context of changes in oil world prices, quite effectively can insulate the domestic economy from international price fluctuations. If the economy is forced to adjust to the fall in world prices without offsetting changes in foreign savings, the resulting loss of export earnings and associated depreciation have major impacts on aggregate absorption, and the structure of production.

\section{References}

[1] Fasano, U., and Q. Wang (2001). "Fiscal Expenditure Policy and Non-Oil Economic Growth: Evidence from GCC Countries". IMF Middle East Department, Working Paper No 01/195.

[2] Fasano, U., and Z. Iqbal (2002). "Common Currency: GCC countries face found mental choices as they head for monetary union". In "Finance and Development", December 2002, Volume 39, Number 4, IMF, Washington D.C.

[3] Fasanon, U., and Q. Wang (2002). "Testing the Relationship between Government Spending and Revenue: Evidence from GCC Countries". IMF Middle East Department and Development and Review Department, Working Paper No. 02/201.

[4] Francois, J., van MEIJL, H., and van Tongeren, F. (2003). "Economic Benefits of the Doha Round for the Netherlands, Agricultural Economics Research Institute (LEI), the Hague, January.

[5] Ghamdi, A. (1991). "Revenue Fluctuations and Current and Development Expenditures in the GCC Countries". Development Policy Review, Vol. 9.

[6] Ginsburgh, V., and M. Keyzer. (1997). "The structure of applied general equi $\neg$ librium models". Cambridge, Mass., U.S.A.: MIT Press.

[7] Habito, C.F. (1984). "Equity and Efficiency Trade-Offs in Philippine Tax Policy Analysis: A General Equilibrium Approach", Ph.D. Dissertation, Harvard University.

[8] Haddad, Eduardo and Hewings, Geoffrey (2003), "Interregional Computable General Equilibrium Models: A Survey on Specification and Implementation Issues", TD Nereus.

[9] Hausner, Ulrich, (1999). "A1995 Social Accounting Matrix for Zambia", Trade and Macroeconomics Division, International Food Policy Research Institute, Washington, D.C. 
[10] Hertel, T. W., and Martin, W. (2001). "Second-Best Linkages and the Gains from Global Reform of Manufactures Trade", Review of International Economics, Vol. 9, No. 2 (May), pp. 215-232.

[11] Hertel, T., Preckel, P., Granfield, J. and M. Ivanic (2001). "Multilateral Trade Liberalization and Poverty Reduction," Memo, Purdue University.

[12] International Monetary Fund (2001). "Public Information Notices on Saudi Arabia for the year 2000", IMF, Washington D.C.

[13] International Monetary Fund (2002). "Public Information Notices on Saudi Arabia for the year 2001", IMF, Washington D.C.

[14] International Monetary Fund (2003). "Public Information Notices on Saudi Arabia for the year 2002", IMF, Washington D.C.

[15] IMF and WB (2002), "Market Access for Developing Country Exports" -Selected Issues, report prepared by the staffs of the International Monetary Fund and the World Bank, September 26, http://www.imf.org/external/np/pdr/ma/2002/eng/092602.htm

[16] Johansen, L. (1960). "A multi-sectoral study of economic growth", Amsterdam: North-Holland Publishing Co.

[17] Joseph F. Francois and Kenneth A. Reinet, (1997). "Applied Methods for Trade Policy Analysis". Cambridge, MA: Cambridge University Press, 224225.

[18] Karadag, M., Westaway, T. (1999). “A SAM-Based Computable General Equilibrium Model of the Turkish Economy". Working paper of Centre for International Financial and Economics Research, Loughborough University.

[19] Kenc, Turalay. (1992). "Dynamic General Equilibrium Tax Modelling: A Study of the UK in the 1980's", PhD Dissertation, The University of York.

[20] Kearney, M., and J.H. van Heerden (2002). "A Static, Stylized, CGE model applied to evaluate the incidence of Value Added Tax in South Africa", Working paper.

[21] Levin, J. and J.K. Thisen (2003). "Optimal Commodity Taxation, Efficiency and Equity Aspects", paper presented at the Expert Group Meeting organized by the UN Economic Commission for Africa on "Fiscal Policy and Growth in Africa: Fiscal Federalism, Decentralization and the Incidence of Taxation", Addis Ababa, 7-9 October 2003.

[22] Löfgren, Hans, and Doukkali, Rachid, (eds.), (1997). "Rural Development in Morocco: Alternative scenarios to the year 2000", International Food Policy Research Institute, Washington, D.C.

[23] Löfgren, Hans (1999). "Trade Reform and the Poor in Morocco: A RuralUrban General Equilibrium Analysis of Reduced Protection", International Food Policy Research Institute, Trade and Macroeconomics Division, Washington, D.C.

[24] Löfgren, H., Robinson, S. (eds.), (2004). "A Social Accounting Matrix for Kuwait 2001". 
[25] Löfgren, H., El-Said, M. and S. Robinson (1999). “Trade Liberalization and Complementary Domestic Policies: A Rural-Urban General Equilibrium Analysis of Morocco," TMD Discussion Paper No. 41, IFPRI, Washington.

[26] Löfgren, H. and M. El-Said (1999). "A General Equilibrium Analysis of Alternative Scenarios for Food Subsidy in Egypt," TMD Discussion Paper No. 48, IFPRI (http://www.cgiar.org/IFPRI), Washington.

[27] Lofgren, Robinson, Thomas, and El-Said. (2002). "A standard computable general equilibrium (CGE) Model in GAMS", Microcomputers in policy research 5.

[28] Lofgren, Hans. (2000a). "Exercises in general equilibrium modelling using GAMS". Microcomputers in Policy Research, vol. 4a. Washington, D.C.: International Food Policy Research Institute.

[29] Lofgren, Hans. (2000b). "Key to exercises in general equilibrium modelling using GAMS". Microcomputers in Policy Research, vol. 4b. Washing 7 ton, D.C.: International Food Policy Research Institute.

[30] Mabro, R. (1991). "OPEC and the price of oil". The energy journal, 13: pp. 1-17.

[31] Mabro, R. (eds) (1986). "The 1986 oil price crisis: Economic effects and policy responses", Oxford: Oxford Institute for Energy Studies.

[32] Mabro, R. (1984). "On Oil Price Concept". Working paper, Oxford institute for energy.

[33] Matusz, S. J. and Tarr, D. (1999). “Adjusting to Trade Policy Reform”, World Bank Working Paper \#2142, World Bank, Washington, DC, July, http://econ.worldbank.org/view.php?type $=5 \& \mathrm{id}=427$.

[34] Ministry of Economy and Planning. 2003a. National Accounts of Saudi Arabia.

[35] Ministry of Economy and Planning. 2003b. Input-Output Table for Saudi Arabia.

[36] Ministry of Economy and Planning website: 〈www.planning.gov.sa>

[37] Morrisson, C. (1991). "Adjustment, Incomes and Poverty in Morocco", World Development, 19(11), 1633-51.

[38] Newberry, D.M. (1997). "Optimal Tax Rates and Tax Design during Systematic Reform", Journal of Public Economics, Vol 63.

[39] Nielsen, Chantal Pohl. (2002). "Social Accounting Matrices for Vietnam 1996 and 1997”. Trade and Macroeconomics Division Discussion Paper 86. Washington, D.C.: IFPRI.

[40] Piggott, J., Whalley, J. (1976). "General Equilibrium Investigations of U.K. Tax Subsidy Policy: A Progress Report”. In Studies in Modern Economic Analysis, Oxford: Basil Blackwell.

[41] Pyatt, G. (1988). "A SAM approach to modelling". Journal of Policy Modelling, 10: 327.352.

[42] Pyatt, G., and J. I. Round (eds.). (1985). "Social Accounting Matrices: A Basis for Planning". Washington, D.C.: The World Bank. 
[43] Presley, John. R. (2000). "The SABIERC economic report on Saudi Arabia". The Saudi British Bank.

[44] Ramady, M.A. (2005). "The Saudi Arabian Economy: Policies, Achievements and Challenges", Springer.

[45] Ramsey (1927). "A Contribution to the theory of Taxation", Economic Journal, Vol.37.

[46] Ranis, G., F. Stewart, and E. A. Reyes. (1989). "Linkages in development: A Philippine case study". Working Paper Series No. 89.02. Manila: Philippine Institute for Development Studies.

[47] Rattsø, J. (1982). "Different macro closures of the original Johansen model and their impact on policy evaluation". Journal of Policy Modelling 4 (1): 85-97.

[48] Reinert, K. A., and D. W. Roland-Holst. (1997). "Social accounting matrices". In Applied methods for trade policy analysis: A handbook, ed. J. F. Francois and K. A. Reinert. New York: Cambridge University Press, 94121.

[49] Robinson, S., A. Cattaneo, and M. El-Said. (1998). "Estimating a social accounting matrix using cross entropy methods". TMD Discussion Paper 33. International Food Policy Research Institute. Washington, D.C. 